\title{
Article \\ Work division processes in social work with Cuban and Norwegian families
}

by

Siv Oltedal (corresponding author)

Professor

Department of Social Studies, University of Stavanger

Norway

E-mail: siv.oltedal@uis.no

Angela Peña,

Professor

Department of Sociology, University of Havana

Cuba

E-mail: angelap@ffh.uh.cu

Sarah Catherine Patricia Duff Hean

Professor

Department of Social Studies, University of Stavanger

Norway

E-mail: sarah.c.hean@uis.no

\section{Keywords:}

Cuba, Norway, familalized and de-familialized welfare regimes, social work processes

DOI: https://doi.org/10.31265/jcsw.v14.i1.237

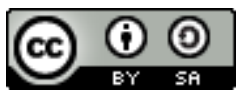

This work is licensed under a Creative Commons Attribution-ShareAlike 4.0 International License. 


\section{Abstract}

\section{English}

This paper explores the differences and similarities in three social work processes as viewed by social workers in Norway and Cuba. Contrasting social work processes in these exemplars of de-familialized and familialized welfare contexts offer insight into where social work practices can be governed by international and universal policy, and where context specific national policies may be more appropriate.

A qualitative study and thematic analysis based on four focus group interviews (two in each country), with a total of 19 social workers from the respective contexts, were conducted. An international validated vignette of a typical social work case was employed as a tool to help facilitate a group interaction and discussion.

The first is an engagement process: how social workers make their decisions on how, or if, to engage with clients. Both Cuban and Norwegian social workers will respond to a client in need, prioritizing children in particular.

A second process related to the social worker is needing to obtain a considered overview of the case. Norwegian social workers rely heavily on information about the case coming from the client, and formal rules restrict information flows between services. In Cuba, clients are important and the participation of the family is obligatory, with social workers drawing on a wide group of stakeholders to gather information.

The final process is one of distributing responsibility for care and support among the appropriate services and actors. In Cuba, social workers emphasize the family`s role in resolving the case. There is a cultural element here based on the role of the family, but a lack of state services and resources available for social workers in practice is also relevant. In Norway, the Welfare State presents more resources, although social workers refer instead to difficulties in coordination between services. Professionals are held to account in Cuba, whereas institutions take responsibility in Norway.

Keywords: Cuba, Norway, familalized and de-familialized welfare regimes, social work processes 


\section{Spanish}

\section{Procesos de división del trabajo en Trabajo social con familias en Cuba y}

\section{Noruega.}

Este artículo explora las diferencias y similitudes en tres procesos del trabajo social a partir de la visión de trabajadores sociales de Noruega y Cuba. A partir de contrastar los procesos del trabajo social en estos casos ejemplares de contextos de bienestar de-familiarista y familiarista respectivamente, el artículo ofrece una visión de hasta dónde la práctica del trabajo social puede estar gobernada por políticas universales e internacionales, y hasta dónde lecturas más específicas según el contexto de las políticas nacionales puede ser más apropiado. Fue desarrollado un estudio cualitativo con un análisis temático basado en cuatro entrevistas a grupos focales (dos en cada país), con un total de 19 trabajadores sociales en ambos contextos. Par el estudio temático se utilizó una viñeta que valida un caso típico para el trabajo social, como herramienta que facilitó la interacción grupal y la discusión. El primer proceso identificado fue el de comprometimiento con el caso: este alude a cómo los trabajadores sociales toman sus decisiones sobre cómo se involucran, o incluso si lo hacen o no, con los clientes. Trabajadores sociales de ambos países responderán a un cliente que lo necesite, priorizando en particular a los niños. Un segundo proceso se relaciona con la necesidad de los trabajadores sociales de obtener una descripción adecuada del caso. Trabajadores sociales de Noruega se apoyan fuertemente en la información proveída por el cliente y en las reglas formales que restringen el flujo de información entre los servicios. Para el caso de los cubanos, los clientes son importantes, y la participación de la familia es vista como obligatoria, pero se apoyan en un amplio grupo de posibles interesados para recopilar información. El proceso final tiene que ver con la distribución de responsabilidades de cuidado y apoyo entre los servicios apropiados y los actores. En Cuba los trabajadores sociales enfatizan en el rol de la familia para la resolución de los casos. Aquí se aprecia un elemento cultural que refuerza la intervención de la familia, pero a la vez la escasez de servicios públicos o recursos para la práctica del trabajo social en familias. En Noruega, el Estado de Bienestar ofrece más recursos, pero los trabajadores sociales refieren en cambio dificultades para la coordinación de la variedad de servicios disponibles. Los profesionales en Cuba retienen más responsabilidad, mientras que en Noruega las instituciones toman más responsabilidades. 
Journal of Comparative Social Work 2019/1

Palabras clave: Cuba, Noruega, regímenes de bienestar familiaristas y defamiliaristas, procesos del trabajo social. 


\section{Introduction}

Social workers all around the world deal with family complexity in their everyday practice. However, little is known about whether social workers from different countries share a common understanding of their practice, and where differences and similarities in social work processes lie. Such an understanding is important as social workers build an awareness of where social work practices can be governed by international and universal policy, and where context-specific national policies may be more appropriate. Some suggest that context does not make a substantial impact on social workers' discussions of the 'important issues in social work and social policy' (Lyngstad, 2015, p. 18), whereas others suggest social work is still contextually dependent, even if international codes of ethics and the main source of ideas identified in social work literature are globalized (Healy, 2014; Oltedal \& Nygren, 2019; Studsrød et al., 2018; Healy \& Oltedal, 2010).

A key dimension of context is national family policy, which varies from country to country, but has in common the need to achieve some form of balance between family, state, market and civil society responsibilities. The dominance of one actor over another can be described on a spectrum of defamiliarized to familiarized welfare regimes (Hantrais, 2004). The former places a greater emphasis on the intervention of the state in the welfare of the individual, thus minimizing their reliance on the input and support of their family members. The latter tips the balance in favour of a noninterventionist approach and a reliance on strong family relationships.

This paper contributes to this debate on the impact of context by exploring differences and similarities in social work practice and processes in familialized or defamilialized family regimes. Comparing social work practices in countries with these particularly contrasting family policies is useful, as it highlights key similarities and differences in national social work processes. A comparison is specifically drawn between Cuba and Norway. Norway is typical of a de-familialized regime, with the state playing a strong role in the regulation of family life, demonstrated by a range of universally available public welfare services, paid for by the tax payer and labour market and gender equality policies (Esping-Andersen, 1990; Pedersen \& Kuhnle, 2017). On the other hand, Cuba is best described as a familiarized regime as, although Cuban social policies are based on universalism, gratuity and social 
solidarity, the individual is more reliant on the contribution of family or other social networks. This is potentially the consequence of the state lacking the resources to fully satisfy the social needs of its citizens, thereby forcing families to assume a full or partial responsibility for services traditionally granted by the State. This situation has been formalized in recent social policy changes, which promote the greater responsibility of the family in Cuba (Peña, 2017) and internationally spell out the state-family, and more recently, state-child relationships (Wyness, 2014).

\section{Methods}

The study was part of a wider EU New Opportunities for Research Funding Agency Cooperation in Europe (NORFACE)-funded project entitled: Family complexity and social work in different welfare regimes. The aim of this project was an international comparison of social work processes. Processes in social work focus on how things are done or achieved. 'The idea of process integrates the people involved, their social contexts and their actions in relation to one another' (Payne, 2006, p. 67).

Social work processes were explored with social workers through four focus group interviews (two in each country, $n=19$ participants). These explored social work processes using a vignette validated in the two country contexts as stimulus (see Figure 1). Focus groups were chosen as a tool best suited to help capture an indepth qualitative discussion of the research theme, enhanced by group discussions and interactions (Krueger \& Casey, 2000). The first two authors (Oltedal and Peña) facilitated one of the Cuban focus groups, while the first researcher (Peña) facilitated the other one. In Norway, the focus groups were arranged by one of the authors and another one of the other local NORFACE project members. The Cuban focus group consisted of four social workers specializing in mental health services, all of them female with between 20 to 45 years of practice. The other focus group consisted of one social worker, two psycho-pedagogic experts, one psychologist and one psychiatrist, four females and one male, respectively, all with between five to 25 years of experience in a communitarian mental health service. One of the Norwegian focus groups was conducted with five female social workers in a mental health service and the other five female social workers from a drug addiction service. 
Focus groups were conducted in one session over a period of two hours. A common written interview guide was used by the facilitator of all focus group sessions, with those participating in the focus group encouraged by the facilitator to refer to both this particular situation and to their own experiences and professional contexts.

\section{The vignette}

Project members from Mexico, Chile, Lithuania, Bulgaria, Ireland, England, Norway and Sweden combined their expertise in social work practice and family policy to develop a vignette describing a generic and complex family situation specifically related to mental health and drug issues that required social work intervention. For the purpose of this research, the vignette was translated and validated for the national context by researchers/social workers from Norway and Cuba.

Vignettes have been a useful tool with which participants may be able to express and share opinions and experiences on sensitive subjects (Brondani et al., 2008). To help establish the trustworthiness of the vignette as a tool to stimulate discussion, it is important that the vignette be seen as a narrative or text that mirrors the social worker's own experience. The text was developed by the NORFACE team, a team comprised of trained social workers that came together to discuss the relevance of the text to their individual national contexts, and adapt this where necessary to a vignette that was nationally appropriate. As a further national credibility check of the vignette, social workers participating in the focus groups in both Cuba and Norway were asked to comment on the relevance of the text to their own experiences (Spalding \& Philipps, 2007). 
Maria*Williams and David Bey live with their three children, Beth (5), John (8) and Thomas (20), who has a different father with whom he has lost contact. Maria is unemployed and David usually works unpredictable hours. David migrated to Chile/Lithuania/Norway/UK, and has no relatives living there. Maria and David often argue, and their relationship is volatile. Maria has a history of heavy drinking and drug use. Maria and the children have sometimes gone to stay with Maria's brother (Paul) and his wife (Hannah). Hannah has four children (ages 8-15) from a previous relationship. Maria and Paul have a younger sister (Lisa) who lives in another part of the country and has little contact with the family. Maria and Paul's parents live outside of the city, and have expressed negative views about Maria and David's relationship; there is also little contact between Maria, David and the three children, and the maternal grandparents.

Stage 1 is a telephone call from Maria to the social worker. Maria describes difficulties she is experiencing (which include arguments with David), Thomas's mental health problems, a little about David's situation and reports that she receives some support from Paul and Hannah.

Stage 2 is presented as a telephone call between a social worker and a mental health worker, who expresses concerns about Maria's progress in relation to her mental health and drinking, her relationship with David and the family situation. Maria, Beth and John also frequently stay with Paul and Hannah.

Stage 3 is presented as a social worker talking to colleagues about the case. Factors such as the children's behaviours in school, Maria's drinking (she was reported as attending Beth and John's school drunk), the family's accommodation and David's potentially precarious immigration status are included. This stage also discusses David's wish to take the children to see his extended (birth) family.

Figure 1: Brief summary of vignette (adapted from Walsh et al., 2018, p. 4)

The full vignette, and the instructions given to the focus groups, are available at bit.ly/FACSK2.

Ethical clearance followed the rules of the Norwegian social science data service (NSD). In the Cuban case, there is no formal ethics committee available; however, researchers explained the purpose of the research to participants, and explained to them how data collected from them would be used and reported anonymously. They then gave their signed written consent to participate.

The focus group interviews were transcribed verbatim, and QSR NVivo 10 was used to assist in the management of the data. An inductive thematic analysis of the first focus group transcript was conducted by the third author following methods 
recommended by Graneheim and Lundman (2004) to create an initial coding framework. This involved familiarization, the identification of meaning units (usually a sentence or groups of sentences that capture a single concept or idea) and assigning each meaning unit a brief heading summarizing its meaning in an open coding process. These codes were grouped into higher level categories, clearly rationalizing the membership of each category in a constant comparison of the categories. Subthemes and themes that represented the concept underpinning a category or group of categories were created through a process of abstraction. The initial analysis, the creation of categories and themes and an overall description of each theme was shared with the first and second authors to confirm the trustworthiness of the categorization and abstraction process (Shenton, 2004). The approved coding framework was then applied to the remaining transcripts, thereby expanding and developing the coding framework in an iterative and collaborative process among the three authors.

\section{Results}

The analysis identified three main themes, or work processes, key to social work practice common across the two case countries examined. The first was defined as engagement processes, the second processes related to acquiring a considered overview of the case and the third, processes of distributing responsibility. In the following description and interpretation of the empirical data, we have used these theme headings to structure our presentation of findings and discussions.

\section{Engagement processes}

When focus group participants in both countries were confronted with a description of a family situation and their challenges (Figure 1), they described different triggers that get them engaged with the client at the initial phase of their social work practice. They often first asked whether the service user (Maria, the mother) had come to the right place: Why had the service user engaged with their particular service rather than another? However, they confirmed that the text presented issues that were relevant for their institution, suggesting that service user engagement with a service in practice in both countries does not always follow specified and expected pathways and points of entry. There were differences related to the range of professionals in each country that participants felt should or would already have been involved in the 
case: In Cuba, it was suggested that schools or community organizations would already have been involved in Maria's case prior to her approaching their specialized services. In Norway, participants felt it would have been unlikely that the client in the vignette would contact them directly because of their specialist status, either at mental health or drug addiction units. A referral was required to them from other, probably municipality services. Nonetheless, in both contexts the professionals in the service indicated that, despite the lack of correct referral, they would still strive towards finding solutions or mediate help for the people in the case. The Norwegian participants said they would have engaged with the user despite their specialist status, whereas the Cubans indicated that they would also engage without a referral if it is considered an emergency case. A Norwegian focus group participant, (NP), said the following:

But we do have some duties anyway. I mean, we don't know why she called me. ...there are, after all, other systems in the welfare state that we work with... (NP)

The presence of children in the vignette made it that participants saw their engagement as a priority, both in Cuba and Norway. This is driven by their own perceptions of the norms and rules that govern the profession and services, namely that participants feel obliged to take action if children are involved and the home situation is seen as unsafe, which is perhaps due to substance misuse or the threat of violence:

I think the priority right now, in the conditions the case is presented right now, I think we must centre the attention on the children. We have to see the children as the main priority now, we have to prevent Maria's condition from continuing to affect their life so badly. This is why I think that if something is still an imperious need it requires the immediate attention to the children. (Cuban Focus group participant, CP)

This quote expresses Cuban professionals' concern with the situation of children and their safety. The quotation shows how social workers set their priorities in complex cases, as children are understood as the main focus of attention and the most critical. In Norway, they underscore a similar point, stating that the law tells workers in different health and welfare systems to focus on children:

But taking care of the kids, first and foremost, I would say is the most important.(NP)

Everyone who works here has a duty, both to the law and procedures, to see the children and ensure and assess how they are doing, and to ensure that they receive some form of help. If it's not from us, then ensure that it's found. (NP) 
Professionals in both contexts see it as essential that the children are being taken care of, but that this can be challenging in both contexts. In Cuba this is due to lack of resources, while in Norway the problem is a lack of coordination that results in users not getting in touch with the right system. Part of the Cuban professional ethos is to explore how they approach users to contribute to their needs, for example, to avoid the problem of clients falling into 'grey zones' where nobody takes responsibility for their care:

Yes, because I am telling you what we have as a norm, as a rule, let's say as a regulation, but it depends mostly on the involvement of the social worker, if we are not involved in the case, and we relate to the case even as a personal matter, it is difficult to get some results. For example, if the patient goes to the psychiatric hospital and a social worker is not involved in the case, then the patient goes back to the community as no one else's problem. I think mental health is depressed as well in the community, many services have been restructured and other centres are closed, so we do not find a mental health centre in every community, and in these communities the social worker has to be more involved and more aware. (CP)

The Norwegian informants dealt with these issues on a more formal basis in relation to discussing who is responsible. They discussed that they would get engaged dependent on which 'hat' they had on:

After all, I'm sitting here thinking... when we are thinking about these sorts of things, then, I notice now that we completely rely on knowing which hat I'm wearing, what is my standpoint? Because we identify and develop thoughts based on where we work. (NP)

And even if they decide that they cannot do anything, they feel they have a duty to help Maria to get in touch with a proper institutional arrangement:

Because where I sit, I can't start working with her there, but I have a duty to help her, perhaps via our systems or via other systems elsewhere that we know about. But we are sitting in different places here. (NP)

This theme suggests that social workers in both countries see their different and formal positions in the welfare system as dictating actions and their different responsibilities. However, in both contexts, regardless of the welfare model and architecture of services, social workers will respond to a client in need and prioritize children and their safety in particular. Yet, it is possible to see that dealing with such a priority differs depending on the specific model where it takes place. In Cuba, the family is an informal network, a pillar of any intervention introduced by the worker along with other communitarian actors. Social workers explain this as due to the lack of state services and resources available to social workers in practice. In Norway, the Welfare State presents a more formal frame/resource for social work practice, though 
social workers refer instead to difficulties in coordination between all the available services. The key similarities and differences in this theme between countries are summarized in Table 1:

Table 1: Processes of Engagement

\begin{tabular}{|l|l|l|}
\hline Theme & Cuba & Norway \\
\hline Processes of Engagement & $\begin{array}{l}\text { The family as an informal } \\
\text { context. }\end{array}$ & $\begin{array}{l}\text { The Welfare State as a } \\
\text { formal context. }\end{array}$ \\
& $\begin{array}{l}\text { Children`s interest get them } \\
\text { engaged } \\
\text { Cack of services due to } \\
\text { reduced resources }\end{array}$ & $\begin{array}{l}\text { engaged } \\
\text { Lack of coordination }\end{array}$ \\
\hline
\end{tabular}

\section{Getting a considered overview of the case}

Both Cubans and Norwegians want to obtain a considered overview regarding key persons involved in the vignette case, and to use this as grounding for their decisionmaking. As a Norwegian expressed it:

Yes, I think we have to sit down and check whether the map matches the terrain. (NP)

Acquiring a good overview of the case was seen as important before approaching other institutions:

There are so many thoughts here, that it makes me think that it's important to get an overview of the situation here before you get in touch with the various support agencies that you think might be of help. (NP)

In Norwegian focus group discussions, they describe that the main source of information about the case comes from the client or key person in the case themselves. (e.g. Maria). This was different in Cuba. They spoke very often about the client not being the one who makes the first call for help:

Actually, very often the community social worker gets information from some sources and starts working on a case with the family doctor. (CP)

They speak of how NGOs like the CDR (Revolution Defense Committee) and FMC (Cuban Women Federation) frequently raise the identify of potential cases well before the patient asks for help themselves:

Yes but if the family doctor fails, I am sure the teachers would see something by children's behaviour. Or the CDR or FMC would see something in the mother or the family, so, the social system would get the information from some of these sources we have, for this reference and counter reference we are talking about here. The information flows in the community. Even the factors of the community have the 
responsibility to visit schools and to identify the problems of the children at school. So the information will be brought to the discussion by some of these factors. (CP)

The ease of information flow within the Cuban community and the active involvement with different organizations makes this possible. It is more difficult to achieve this in the more restricted Norwegian context. For example, when children are involved, Norwegian social workers report the clear rules for how to report:

I have largely worked with young people, but as a rule child welfare gets involved pretty quickly when children are involved... in my experience they get involved at once then. Before the child is born and immediately afterwards (NP)

Cuban participants described how, as professionals, they are responsible for gathering the work of other actors such as families, community, formal and informal leaders and institutions. The flip side of this is that Cuban participants describe that a lot of discretion is required, and that there is not much developed policy to guide them in this area:

But I must say that there is not an official statement about these topics of what the concept of family is, or what is the role of each institution and so on; there is not a proper protocol for dealing with families with complex needs. It actually depends on the discretion of the specialists who work on each case. We do have protocols as social workers about when, how and who we may help with assistance and goods, material goods above all. But the conduction of a case during a long lapse of time depends very much on the conditions, capacitation and involvement of the social workers and other professionals working in every stage of cases' evolution. (CP)

The main tool for getting a considered overview of what is going on is engaging with the clients themselves, as setting up a conversation with a client is seen as essential. The means of doing so lies along a continuum of intimacy from a phone call on the one hand, and a consultation at the service offices or to a home visit on the other.

Cuban social workers expressed a need to establish what really is going on in the case. Home visits are an essential form of contact to establish a broader perspective:

One thing is what Maria told us by the phone call, but we have to go to the house, and to discuss the case with the team to get a better understanding before planning any action. (CP)

In the Cuban focus group discussion, they elaborate further on how it is important to obtain sources other than the information from Maria and her interpretation of the situation:

In this case, we would have to see the situation of the children, because even when Maria says they are well, we have to see other sources of information such as the 
school, the community factors and about all we have to do to schedule an appointment with David as the father in this family. We need to think that the case can't be evaluated by Maria's telling. (CP)

In the Norwegian material, we critically reflect on Maria's interpretation of the situation. She is both saying that the children are OK, and that they are not OK. A way of dealing with these contradictions in information provided by the client is similar to the Cuban approach, to go on a home visit and acquire a broader perspective on the situation:

But she is opposing, she's saying that the kids are getting beaten, and I'm also thinking about that. She says that: they're okay fortunately. Like, right at the end. So I feel that l'd be very worried about how bad it really is. She's undermining in a way, at the end there, so I think that it's so important to make a home visit and check what is going on in the home. (NP)

The family may be a source of further information if required. Historically, this has been more difficult for the Norwegian practitioners to achieve, as social workers had not been able to gather information directly from children during family meetings. They now report being permitted direct access to the children. This means the social worker can directly reassure the children, rather than rely on other family members to mediate the intervention. The Norwegians speak of it being:

... vitally important that the kids themselves can put into words and be heard, how they experience the situation, and not just from what their parents think. (NP)

The increased focus on the situation of the child is shown in how municipalities prioritize resources to this area:

And now it's actually sort of the case that, at least here in [place] that they select people who have responsibility for children, not to take all responsibility, but to ensure that the unit functions in relation to the perspective of the children. Such that in our partner municipalities, the four we have, all four municipalities have a defined person responsible for children, although the law says that it is only the specialist health services that must have this, such that there are some important resources involved, and that the agencies deal with adults today in relation to obligations vis-à-vis children. (NP)

It both contexts, relying on the information provided by the client to receive an overview of the case is not seen as sufficient, with the need for participation of the family highlighted as essential in information gathering. A summary of the similarities and differences between country contexts in this theme is presented in Table 2: 
Table 2: Getting a considered overview of the case

\begin{tabular}{|l|l|l|}
\hline Theme & Cuba & Norway \\
\hline $\begin{array}{l}\text { Getting a considered } \\
\text { overview of the case }\end{array}$ & $\begin{array}{l}\text { Home visit to investigate } \\
\text { information } \\
\text { Family has obligations } \\
\text { Broad focus of collecting } \\
\text { information }\end{array}$ & $\begin{array}{l}\text { Home visit to investigate } \\
\text { information }\end{array}$ \\
Family as possible helper \\
$\begin{array}{l}\text { Strict focus of collecting } \\
\text { information }\end{array}$ \\
\hline
\end{tabular}

\section{Distributing responsibility between actors}

Participants from both countries discussed how the first step in distributing responsibility between actors is that the service user (with or without the facilitation of the social worker) acknowledges and accepts the need for support from others (professionals, services and other family members) and not go it alone. Contingent to this is that the client then gives their permission for the social worker to engage the available resources. It is understood in the material from these two different contexts that the Norwegian Child Welfare (CW) is an institution that Norwegians are more afraid of than what seems to be the situation with the Commission for attending to minors (CAM) in Cuba.

The social workers in Norway then see their key responsibility or role as one of resource gatherer or conduit, through which clients can gain access and support from the resources of other services and/or the resources of the client's other family members. Here, a Norwegian social worker underscores the need for a coordinating role in complex cases, and that this is a central role of the social worker:

I sit in a ward so I couldn't have done very much there, but I would have to ensure that someone got to grips with it. Because I'm sure there are many agencies involved and that will be involved here, so there certainly has to be some coordination in the midst of all of this. (NP)

Similarly, in Cuba they emphasize the coordinator role of the social worker:

The mental health centre would manage the integration of all the services and the institutions that could be involved here, the centre is the closest service to the community. In the centre, the social worker has an important role to play because the social worker is the one who deals with the case as a whole. (CP)

And as another Cuban participant expresses:

We know the resources we can count on, and this is our role. Our task is to fight for these resources to work on this case. (CP) 
In Norway they stress the importance of the municipality and front line services.

Child welfare services are seen as particularly relevant:

I just think that given the way the system is now, that we do have to... after all, everything possible should be done via the front line service, right? So, the frontline service should really have more of an overview than us in the second line services, I think. (NP)

I also think that child welfare is an incredibly important agency because they are motivation for the parents to change what is not good, and that they have more of the law on their side and can say what is required. (NP)

In Cuba, they describe cooperating with multiple services, also discussing how many stakeholders are already involved with the client, and that their involvement is necessary because the social worker cannot work with the client and their complexities alone. They see themselves as having a central coordination role in integrating the activity of these various services, and then monitoring their progress with the client. They describe themselves as a key link between the individual, their social environment and the services that are able to help them. The role of the social worker is seen as that of a coordinator in both contexts. Part of the role is trying to predict future criseis and how to overcome these.

Cuban professionals have a wider definition of relevant stakeholders than do the Norwegians, however. They look beyond the state and municipal services available to community networks, NGOs and even neighbours, placing a much greater emphasis on the importance of the family as a context in this work. There is a strong emphasis on the importance of the user and the family:

The family is everything, without family there is no treatment possible. (CP)

We have, for example, the signed consent, when they participate in treatments with us. We don't decide. We never decide over our patient. This is a role that corresponds to the family. They are informed about the options, and they approve what to do by a signed consent. Unless it is an emergency, and the therapist must act. (CP)

The family and the informal arena is a very important point of reference in Cuba when coordinating care. Cuban participants refer to drawing on the strong feelings of solidarity in Cuban culture and the extended view of family that exists in this culture. They emphasize the centrality of the family in decision-making and the importance of their cooperation, in addition to taking joint responsibility for the situation. From the 
Cuban context, participants described a shift from institutionalized care to more family care:

For us, years ago, we had the protocol of taking the sick person, the elder, the disabled, all of them who need attention, we had to find an institution where to place them, and treat them out of a family shelter. But now, we have another way of thinking about the solutions, now we think of the family as the main factor in the healing process; in any treatment, we must show family how to deal, how to cope, how to help, how to be part of treatment. And even despite any problem we may have, the community is also seen as a 'social family'. (CP)

This new way of understanding the family role in a social work process is partly cultural. In Cuba, as in many Latin American countries, families are a strong pillar for coping with everyday life. However, in Cuba the state has traditionally tried to provide strong welfare provision, but a lack of resources meant the families' involvement became essential. Recently, the welfare model has formalized this familialized perspective, orienting social services towards a combination of state resources and informal family and community networks.

Although both Norwegians and Cubans discuss the notion of family as a concept and the importance of exploring with the client where positive and negative relationships within it lie, there is a greater focus on keeping children with the family in Cuba. The service context structures available are also different. For example, while in Norway there are foster homes as an option to move children out of their families, in Cuba this option does not exist and the main criterion described by Cuban participants was not to separate the child from his/her family:

Because the family exists and we must work with them. Just in very extreme cases, which are discussed and analyzed in court rooms, then it is possible to evaluate the possibility to remove children from their original family. (CP)

There are two different explanations for the Cuban position: a lack of services that offer any alternative to family involvement, and a cultural perspective that emphasizes family and social networks as extremely relevant to everyday life. Because of the importance of the family in the Cuban context, the relationship between public services and families is highly important:

Society can't take a child away from the mother, or the family in general. And if it is absolutely necessary, the guard and custody go to the grandparents or other relative. But if it happens, only if it happens that the situation is so dangerous and almost impossible to find another solution for the children safety, then children could be moved to someplace else. The concept here is to solve the problems within the family, and to keep the children with their own. Usually if we have violence, the 
aggressor is the one who is taken out of the home by the police or other social intervention. (CP)

There are a range of programmes and communication tools that assist social work practice. In Norway, they refer to different specific tools, such as network meetings, as one way of achieving the wider overview or vision of the whole required to fulfil the social work coordination role. In Cuba, formal meetings are utilized less as a tool, although a brief mention of so-called reference/counter reference protocol interagency meetings is made. The regulation of these meetings is limited, and all stakeholders seen as relevant can attend. These meetings are more restricted and regulated in Norway, and the client must agree upon who should be invited to a network meeting:

Yes, yes, they can of course bring who they want into a responsibility group as a support person. It could be a boss at work or it could be someone who they have a special bond with, who they experience as supportive, and it doesn't need to be family at all. (CP)

The Norwegian participants discuss the running of meetings in greater detail. The presence of the client in the meeting is very important, but at times this participation may be problematic and participants discussed ways in which participants may be helped to feel more at ease and supported. They discuss formal means of establishing dialogue within the group meeting, using methods such as open or anticipatory dialogue techniques:

But, in my experience, in such cases, ... child welfare has often had a dialogue meeting with all of the parties, and in a way stipulated the requirements that there should be, that one should talk openly together in the meeting. (NP)

Overall, Norwegian social workers are more deliberate on what kind of group meetings should be held to bring together a range of human resources, and who should attend, distinguishing between responsibility, cooperation or network-type meetings.

Welfare service delivery appeared more formal in Norwegian participants' descriptions than Cuban ones, with Norwegian social workers often referring to different paragraphs in the Norwegian law on this area. In Norway, for example, there is a law regarding how to define and approach the next of kin:

We had some special procedures before, because we were very early when it comes to working with children and next of kin, but now, of course, national procedures have been introduced and we adopted them last year. And, in a way, just adjusted them a bit and have the five comprehensive procedures that are based on children as next of 
kin. After all, it is both allowed... in the Health Personnel Act, which applies to all health personnel both here and other places, and then there are regulations and procedures, so there is a huge system that has been developed in recent years (....). (NP)

Overall, this distribution of responsibility theme shows how social workers in Cuba have clearly emphasized the family's role in resolving the case. Formal patterns of social work practice do not rely on the family or informal networks in the Norwegian system, but instead on local authorities and services. This distribution of responsibility is not surprising based on the familiarized and defamiliarized natures of the two welfare models, and is related to state resources. However, it also shows that the assignment of responsibility is different in the two counties in terms of whether the professional or the institution is seen to be taking responsibility: in Cuba the former is true, and in Norway the latter. Table 3 summarizes the distribution of responsibility in these two contexts:

Table 3: Distributing responsibility between actors

\begin{tabular}{|l|l|l|}
\hline Theme & Cuba & Norway \\
\hline $\begin{array}{l}\text { Distributing responsibility } \\
\text { between actors }\end{array}$ & $\begin{array}{l}\text { Social worker as a coordinator } \\
\text { role } \\
\text { Few tools and programmes } \\
\text { Activate family and civil society } \\
\text { unit }\end{array}$ & $\begin{array}{l}\text { Several tools and programmes } \\
\text { Involvement of formal child } \\
\text { welfare services }\end{array}$ \\
\hline
\end{tabular}

\section{Discussion}

Cuba and Norway represent familiarized versus de- familiarized approaches to family policy in social work. Despite these differences in regime, however, the countries share underlying processes of social care practice, regardless of national policy.

Social work processes have been previously classified on a temporal basis: as having preparatory, starting, middle, closing and evaluation phases (Compton \& Galaway, 1984; Shulman, 1992; Johnson, 1992; Dominelli, 2004). Alternatively, they can be organized in terms of their content: referral, data gathering, assessment, agreeing on a plan, implementation, evaluation of outcome for those involved and reflection about future actions. In this international comparison between Norway and Chile, social work processes have been largely described in terms of their content, as well as three specific substantively distinct phases shared in the practices of both 
country's professionals: processes associated with engaging with the client, obtaining a considered overview of the clients situation and lastly the distribution of responsibility between actors or resources to support the client.

In the engagement process phase of social work practice, pathways of entry for the client are not always clear-cut. Participants considered their position within a specialized service and questioned whether a client should come to them. Both Norwegian and Cuban professionals work within a formal position within specialized services. This means there is a stated pathway for developing a formal contact with the user, and this is regulated by the institutions they are working within. Despite this, their value and motivation to help will override these concerns, especially if children are involved.

Even so, differences between Norway and Cuba are noted. When help is offered by a social worker, the formal interagency context is underscored in the Norwegian context, while the informal family context is most important in the Cuban context. The formal and informal role of family effect the engagement process phase. The availability of resources and strict protocols in Norway provides social workers with a structure for practice. Their challenges relate to coordination and the identification of the proper service to be involved, or the proper 'hat to wear'. On the other hand, for Cuban social workers the lack of resources and absence of strict protocols that come with the familialized model allow social workers to be more creative and flexible regarding what services and actors can participate in case resolution. However, this flexibility may mean social workers are not fully involved or committed to cases, believing others will take responsibility instead. Thus, here we see the example of a familialized and de-familialized family regime. This provides a different context for social work processes, and we anticipate that this will inform how social workers implement the engagement phase in these different contexts. In both contexts, social workers prioritize the case because of the presence of children in the case. In Norway, there are laws and regulation that govern this prioritization. There are less formal guidelines in Cuba, and strong social and cultural norms are more dominant in the regulation of this area. 
Professionals from both countries are concerned about clients and families falling into grey zones between services. In Cuba, these zones appear to be caused by a lack of resources and, in Norway, by a lack of coordination of services. In Cuba, social workers fear that if they do not help somebody nobody will help the needy, while in Norway the worry is that the different institutions believe the client to be another institution's responsibility. We could anticipate that the Cuban social workers feels this to be a personal challenge, and therefore take more personal responsibility to act than the Norwegian social worker, who proclaims it as a challenge for the institution or the system. Still, breaking rules related to the laws will have specific consequences for the Norwegian practitioner compared to general moral sanctions when breaking norms within the Cuban system. Consequently, there are closer relations between policy and practice in Norway than in Cuba, something that is found to be similar to findings elsewhere in comparisons among Mexico, Chile and Norway elsewhere (Studsrød, Ellingsen, Guzmán, \& Espinoza, 2018).

In the process of getting a considered overview, professionals describe in both contexts how they will relate toward Maria as the main user. They will be friendly, building a relationship based on confidence, and they will use professional discretion when they interpret the situation. They both question the consistency of the information provided by Maria about the family situation. Both groups would collect alternative information through a home visit to see for themselves. Cubans are happy to obtain further information from a broader range of sources. This is possibly related to easier flows of communication or less restrictions on communication between stakeholders. Everybody is seen as able and obliged to contribute to supporting the family. Cubans also see the involvement of the family in providing information and support as obligatory, whereas this is encouraged but less central in Norwegian social work practices. Nonetheless, the flip side of this less constrained communication is that again the social worker has little formal guidance to guide their actions. In Norway, communication lines are more tightly controlled. Norwegian institutions within health, education and welfare have a specific responsibility to inform Child Welfare if they are worried about the situation of a child. It is a more ruleoriented system as to who can give information and who can ask for information, compared with the less regulated Cuban context. 
In the distribution of responsibility phase of social work processes, we identified that both in Cuba and Norway the social worker often functions as a coordinator of services. Participants agreed that clients must first want to engage with the support being coordinated, but that the social worker role is then as a resource gatherer and coordinator of this support. Network meetings may be used by both countries as a coordination tool, but the Norwegian meetings are more tightly regulated and more emphasis is placed on how they are run. In Cuba, it is explicitly mentioned that it is the social worker as the individual who has a coordinator role, while the Norwegian social workers described the role of their institution as the coordinator, rather than the task being that of the individual social worker. In Cuba the importance of the municipality has increased, in addition to the NGOs. In Norway, the municipality is also an important coordinating unit. The Cubans have a wider definition of community in terms of contacting the people being engaged to support the client than the Norwegians, as they have a more formal approach regarding who to contact. The Cuban definition of community goes beyond just the services available within the municipality, and includes the family, neighbours and other informal means of support.

Findings also suggest that the relationship between family and the state are different in the two country contexts. In Cuba, it is anticipated that the family and the extended family will take care of the children, for example, and that the state is slowly withdrawing resources from helping out with family challenges. The rise of the family role in the access or limitation to welfare also comes together with the lack of family vision in social policy design (Durán, 2010). This situation is formalized by recent social policy changes toward a more responsible family over an individual's wellbeing (Peña, 2017) (Peña \& Voghon, 2015). In Norway, children are the primary responsibility of the welfare state, and there is a rising focus about the need for the state to ask the children for their opinion on services (Pösö, Skivenes, \& Hestbæk, 2014). Wyness (2014) writes that we have historically seen a change from a statefamily relationship towards a state-child relationship. This is certainly the case in Norway, though less so in Cuba. Social workers have a specific position in the familystate relationship, as they need to address the challenges of both children and their families. The complexities in the relationships among the child, the family and the state spheres have a different blending within various welfare regimes. While in the 
Norwegian situation, there is a focus on the state-child relationship, the situation in Cuba is moving towards strengthening the state-family relationship. For Cubans, the care of the child within the family is more a private matter, with the family viewed as a private system. This is the case if compared to the Norwegian family, where the individual in the family is the focus, and the safety and well-being of the child in the family a public rather than private matter.

\section{Conclusions}

Social workers in Cuba and Norway deal with family complexity in their everyday practice. In this study, we have shown that social workers from Cuba and Norway, despite different welfare models, share a common understanding of their practice. Three common work processes (engagement, assessment and distribution of responsibility) were specifically identified across the two countries, partially agreeing with Lyngstad (2015) that there are globalized social work processes that transcend national borders.

However, we also agree with Healey (2014) and others in their view that contextual aspects also matter. Social care practices that rely more or less heavily on the family for support may well be the product of formal defamiliarized and non-familiarized models of welfare, but other contextual factors such as social norms, culture and national resources may equally affect these practices, or in fact have dictated the welfare model in the first place. In Norway, the Welfare State presents more resources, but social workers refer instead to difficulties in coordination between services. Professionals are held to account in Cuba, whereas institutions take responsibility in Norway.

\section{Acknowledgements}

The Norwegian part of the data collection is funded by NORFACE. 


\section{References}

Brondani, M., MacEntee, M., Bryant, R., \& O’Neill, B. (2008). Using Written Vignettes in Focus Groups Among Older Adults to Discuss Oral Health as a Sensitive Topic, Qualitative Health Research, 18(8): 1145-1153. https://doi.org/10.1177/1049732308320114

Compton, B. R., \& Galaway, B. (1984). Social Work Processes. Illinois: Dorsey Press.

Dominelli, L. (2004). Social work: Theory and practice for a changing profession. Cambridge: Polity Press.

Durán, A. (2010). Transformaciones sociales y familias en Cuba: Desafíos para las políticas sociales [Social transformations and families in Cuba: Challenges for social policy makers]. In Cuadernos CIPS 2009 Experiencias de investigación social en Cuba [Experiences of social research in Cuba], C. Claudia et al. (Eds.), La Habana: Editorial Acuario

Esping-Andersen, G. (1990). The three worlds of welfare capitalism. Princeton, New Jersey: Princeton University Press.

Fleitas, R. (2016). Política social y servicios de salud en Cuba [Social Policy and health services in Cuba]. In Política Social e servico social. Brasil e Cuba em debate [Social Policy and social services: A Brazilian Cuban debate], F. Siqueira, \& T. Muñoz (Eds.), Sao Paulo: Veras Editora.

Gomez, E. (2012). Premisas para el desarrollo del trabajo social en el contexto cubano actual [Premises for Development of Social Work in the real Cuban Context]. In El trabajo Social en Cuba. Retos de la profesion en el siglo XXI [Social work in Cuba: the Profession in the $21^{\text {st }}$ Century], M. Yordi, E. Gomez, \& T. Caballero (Eds.), La Habana: Ediciones Unión.

Graneheim, U. H., \& Lundman, B. (2004). Qualitative content analysis in nursing research: Concepts, procedures and measures to achieve trustworthiness. Nurse Education Today, 24(2), 105-112. https://doi.org/10.1016/j.nedt.2003.10.001

Hantrais, L. (2004). Family policy matters. Responding to family change in Europe. Bristol: The Policy Press. https://doi.org/10.2307/j.ctt1t893wm Healy K. (2014). Social Work Theories in Context: Creating Frameworks for Practice. London: Palgrave. https://doi.org/10.1007/978-1-137-02425-1 
Healy, K., \& S. Oltedal (2010). An institutional Analysis of Child Protection Workforce Turnover. An Australian and Norwegian Comparison. Journal of Social Policy 39(2). 255-274. https://doi.org/10.1017/S004727940999047X

Johnson, L. C. (1992). Social Work Practice. A generalist approach. 4th edition. Boston: Allyn \& Bacon.

Krueger, R. A., \& Casey, M. A. (2000). Focus Groups: A Practical Guide for Applied Research, 3rd ed. Thousand Oaks, CA: Sage Publications.

Muñoz, T., \& de Urrutia, L. (2016). Pensar acerca de la reinstitucionalización del Trabajo Social en Cuba (2011-2015). [Thinking on the reinstitutionalisation of social work in Cuba]. In Política Social e Servico Social. Brasil e Cuba em debate [Social Policy and Social Services: A Brazil and Cuban debate], J. F. Siqueira, \& T. Muñoz (Eds.), Sao Paulo: Veras Editora.

Lyngstad, R. (2015). Different welfare system - same values? How social work educators in Norway, Chile and Argentina comprehend core social work and social policy issues. Social Sciences, 4(1), 239-259.

https://doi.org/10.3390/socsci4010239

Oltedal, S., \& Nygren, L. (2019). Private and public families: Social workers' views on children's and parents' position ,in Chile, England, Lithuania and Norway. Journal of Comparative Social Work, 14(1), https://doi.org/10.31265/jcsw.v14i1.235.

Pedersen, A. W. \& Kuhnle, S. (2017). The Nordic Welfare State Model. In The Nordic Models in Political Science. Challenged, but still alive? O. Knudsen (Ed.), Bergen: Fagbokforlaget.

Peña, A. (2017). Regímenes de bienestar y pobreza familiar en Cuba [Regimes of well-being and family poverty in Cuba]. La Habana: Editorial Nuevo MilenioCiencias Sociales. https://doi.org/10.31265/jcsw.v10i2.132

Peña, A., \& Voghon, R. (2015). Social workers construction of "family" in a Cuban context: Ideas for a debate. Journal of Comparative Social Work, 10(2), 195228. https://doi.org/10.31265/jcsw.v10i2.132.

Pösö, T., Skivenes, M., \& Hestbæk, A-D., (2014). Child protection systems within the Danish, Finnish and Norwegian welfare states-time for a child centric approach?, European Journal of Social Work, 17(4): 475-490. https://doi.org/10.1080/13691457.2013.829802 
Shulman, L. (1992). The Skills of Helping Individuals, Families, and Groups. 3rd edition. Illinois: F.E. Peacock Publishers Inc.

Spalding, N., \& Phillips, T. (2007). Exploring the Use of Vignettes: From Validity to Trustworthiness, Qualitative Health Research, 17(7): 954-962. https://doi.org/10.1177/1049732307306187

Studsrød, I., Ellingsen, I., Guzmán, C., \& Espinoza, S. (2018). Conceptualizations of family and social work family practice in Chile, Mexico and Norway, Social Policy and Society. 17(4):637-645. https://doi.org/10.1017/S1474746418000234 Yordi, M. (2012). Apuntes para un acercamiento a la historia del trabajo social en Cuba [Notes on the historical approaches of social work in Cuba]. In El trabajo social en Cuba. Retos de la profesion en el siglo XXI [Social Work in Cuba in the $21^{\text {st }}$ Century], M. Yordi, E. Gomez, \& T. Caballero (Eds.), La Habana: Ediciones Unión.

Walsh, J., \& Mason, W. (2018). Walking the walk: Changing familial forms, government policy and everyday social work practice in England. Social Policy and Society, 17(4), 603-618. https://doi.org/10.1017/S1474746418000209 Wyness, M. (2014). Children, Family and the State: Revisiting Public and Private Realms. Sociology, 48(1): 59-74. https://doi.org/10.1177/0038038512467712 